\title{
ORCHIDANTHA SARAWAKENSIS SP. NOV. (ZINGIBERALES: LOWIACEAE), A NEW SPECIES ENDEMIG TO EAST MALAYSIA, BORNEO
}

\author{
Syauqina MY*, Meekiong K \& Aimi-Syazana S \\ Department of Plant Science E Environmental Ecology, Faculty of Resource Science and Technology, Universiti Malaysia \\ Sarawak, 94300 Kota Samarahan, Sarawak, Malaysia \\ syauqinamy@gmail.com
}

Submitted November 2018; accepted April 2019

\begin{abstract}
Lowiaceae is one of the eight families in Zingiberales and comprises a single genus, Orchidantha. This genus is restricted to South-East Asia and poorly known among Zingiberales. Currently, there are 25 species including a new species from Sarikei, Sarawak, O. sarawakensis Syauqina \& Meekiong which is described and illustrated in this paper. Orchidantha sarawakensis is compared with species described in South-East Asia and also species described in Borneo. The comparison shows that $O$. sarawakensis is closely related to O. megalantha Škorničk. \& AD Poulsen and O. holttumii K Larsen. The features that delineate O. sarawakensis as a new species is that its labellum possesses a prominent extended midrib throughout the apex with spirallike structure, curved upwards and a Y-shaped secretion tissue called viscidium. A key of Orchidantha to all Malaysian species is presented.
\end{abstract}

Keywords: Orchidantha holttumii, O. megalantha, spiral-like, Sarawak

\section{INTRODUCTION}

Lowiaceae (Zingiberales) comprises the single genus Orchidantha Brown. The first species (Orchidantha borneensis) was described by Brown (1886) from a specimen collected in Borneo (Nagamasu \& Sakai 1999). Thereafter, another two species, O. longiflora Ridl. and O. maxillarioides K. Schum. were described (Keng 1969). All three species were found in Sarawak or Peninsular Malaysia. Several more species were discovered and described in Sarawak, Sabah and Peninsular Malaysia (Larsen 1996, Nagamasu \& Sakai 1999, Pedersen 2001, LeongŠkorničková 2014, Syauqina et al. 2016). To date, the total number of Orchidantha species only found in Malaysia is 16 (including the present new species).

The genus name Orchidantha was proposed by Brown (1886) due to the physical shape of the flower which resembles an orchid flower. The history of the family Lowiaceae was discussed by Syauqina et al. (2016). Orchidantha is restricted to South-East Asia with total of 25 species recorded. In Malaysia, the genus is usually found in mixed dipterocarp forest, kerangas forest, and seldom in limestone forest. It prefers a moist habitat, e.g. near streams in shady areas (Carlquist \& Schneider 1988).
In the field, sterile Orchidantha plants can be easily be mistaken for Hanguana Blume, Tupistra Ker Gawl. or any other monocot with a robust herb habit (Leong-Škorničková 2014). Since their plant habits do not show any glaring differences, flowers play an important part in distinguishing the species. There are three crucial flower parts in Orchidantha that give distinct characteristics to the species, namely, labellum, petal and stigma (Leong-Škorničková 2014). Labellum is the showiest and attractive flower part in Orchidantha flower. The size of labellum could be bigger or the same length as the sepals. Every species has a different shape, size and colour of labellum, which are important keys in differentiating the species. The newly described species and two other closely-related species were examined thoroughly by their flower structure and morphology.

\section{MATERIALS AND METHODS}

The present new species was collected in Sarikei, Sarawak. It was found in open forest area at $100 \mathrm{~m}$ altitude near a stream in Sebangkoi Recreational Park. After evaluating all 15 species of Orchidantha known in Malaysia, 
O. sarawakensis was found nearly similar to O. megalantha Škorničk. \& A.D. Poulsen and to $O$. holttumii $\mathrm{K}$. Larsen in their habit and flower appearance. Description of vegetative and reproductive characters was based on living plants and herbarium specimens, which allowed detailed measurements.

\section{RESULTS}

The new species-Orchidantha sarawakensis Syauqina \& Meekiong sp. nov.

Type: MALAYSIA, Sarawak; Sebangkoi, Sarikei. Sebangkoi Recreational Park. 24 September 2017, Syauqina MY, Meekiong K, Aimi Syazana S, Zahid ZA \& Ivy GNM SS0074 (holotype: SAR, isotype: HUMS)

Diagnosis: Similar to $O$. megalantha and $O$. holttumii but differing in flower size, whereby $O$. megalantha and $O$. holttumii have flowers twice as big as $O$. sarawakensis. The labellum shape is different at the apex (acuminate in O. holttumii and $O$. megalantha while aristate with prominent extended midrib throughout the apex with spiral-like structure and curving upwards in O. sarawakensis). Orchidantha sarawakensis possesses dark purple stigma and Y-shaped viscidium which is distinctly different from O. holttumii (purple stigma with broadly V-shaped viscidium) and $O$. megalantha (cream white with purple tinge stigma and V-shaped viscidium).

Description: Perennial herb with ca. 11 distichous erect leaves, up to $1.5 \mathrm{~m}$ tall, from vertical brown rootstock, with many fibrous roots. Roots sometimes with nodule. Leaves up to $90 \mathrm{~cm}$ long; petiole green, yellowish green towards the base, canaliculate, $41-81 \mathrm{~cm}$ long, $1.8-2.0 \mathrm{~cm}$ in diameter; sheath clasping, wing, $38.5-41 \mathrm{~cm}$ long width $0.9-1.1 \mathrm{~cm}$ in diameter; lamina elliptic to narrowly elliptic 72.3-86.5 $\times$ $12.4-15.6 \mathrm{~cm}$, green both adaxial and abaxial, glabrous, base attenuate, margin entire, apex acute, midvein impressed above. Inflorescences several, basal, few-flowered, panicles, ca. 25.5$30 \mathrm{~cm}$ long; bracts imbricate, lanceolate, apex aristate, yellowish green; peduncle 10-12 cm long, yellowish brown. Flower bud tubular, ca. $5.5 \mathrm{~cm}$ long, pale yellow and red at tip; pedicel ca. $6 \mathrm{~cm}$ long, yellowish brown; floral bract lanceolate, boat-shaped, ca. $5 \mathrm{~cm}$ long $\times 15 \mathrm{~mm}$, pale yellow and purplish pink at apex. Flower sepals 3, approximately of the same length but of different width; dorsal sepal elliptic, ca. $6.2 \mathrm{~cm} \times 1.6 \mathrm{~cm}$, yellowish green and dark yellowish brown at apex; lateral sepals 2 , equally long, overlapping, elliptic, $6.2-6.3 \mathrm{~cm} \times 1-1.1 \mathrm{~cm}$, apex acute to mucronate $(0.3 \mathrm{~cm}$ long), yellowish green and dark yellowish brown at apex. Labellum elliptic, $5.6 \mathrm{~cm} \times 1.2 \mathrm{~cm}$, with parallel and convergent veins, apex aristate, spiralling, $2.6 \mathrm{~cm}$ long, dark purple. Petals 2, linear, $1.8-1.9 \mathrm{~cm} \times 6 \mathrm{~mm}$, margin entire, apex apiculate, $2.6 \mathrm{~cm}$ long dark purple but white at base, glabrous, fused at base. Stamens 5, elongated, $5.9 \mathrm{~cm} \times 0.6 \mathrm{~mm}$, dark purple; style robust, dark purple. Stigma 3-fid, $7.4 \mathrm{~mm}$ long, $2.8 \mathrm{~mm}$ in diameter, margin crenate and dentate, apex like a fish fin, purple; viscidium Y-shaped, white. Ovary, glabrous, $3 \mathrm{~mm}$ diameter, milky white. Fruit not seen.

\section{Habitat, ecology, etymology, and conservation status}

This new species is considered as a hyperendemic species, as is currently recorded only from a single locality in Sarawak. The second author, discovered this plant in Sebangkoi Recreational Park (01'57' 47" N, $\left.111^{\circ} 25^{\prime} 55^{\prime \prime} \mathrm{E}\right)$ near a stream in a dry shaded area of a Kerangas forest. The plants grew in a clump consisting of five individuals. Each clump was 5 to $10 \mathrm{~m}$ from each other. The specific epithet was named after the locality where the species was found, i.e. the state of Sarawak. The population is expected to suffer a decline as the growing number of plants was very low (20-35 individuals) and localised to that particular area. According to the IUCN Red List categories and criteria (Chadburn 2018), this genus has a very small extent of occurrence and is declining in the habitat due to logging and road building. We suggest it should be categorised as 'Endangered' (EN B1ab(iii)+2ab(iii)) .

\section{DISCUSSION}

From the comparison of Orchidantha species in South-East Asia based on species morphological description, protologues and types of specimens, it was found that $O$. sarawakensis has similar stigma structure with $O$. virosa Škorničk. \& Q.B. Nguyen (Leong-Šsorničková et al. 2014) and O. foetida H.Đ. Trần \& Škorničk. (Jenjittikul \& Larsen 2003). Orchidantha virosa share the same 
purple stigma colour and Y-shaped viscidium with $O$. sarawakensis. However, the stigma margin is different; $O$. virosa has minutely fimbriate stigma margin while $O$. sarawakensis has crenate and dentate stigma margin (Figure 1). The only similarity between $O$. foetid $a$ and $O$. sarawakensis is the stigma structure. Stigma colour (greenish white), stigma margin (finely fimbriate) and also shape of viscidium (cordate decurrent along the style) of $O$. foetida are clearly different from $O$. sarawakensis.

Orchidantha species is endemic to Borneo (Poulsen \& Leong-Škorničková 2017) and from 10 previously found species, only O.holttumii and $O$. megalantha are very closely related to $O$. sarawakensis. The size of both $O$. holttumii and O. megalantha were twice bigger than $O$. sarawakensis. These three species show differences in three critical flower parts, i.e. labellum, petal and stigma.

The three species discussed above possess a claw-like labellum, but are different in apex shape. The labellum of $O$. megalantha is crenulate-undulate towards the apex and folding upwards distally with a prominent, thick, straight midvein extension at the acuminate apex. Orchidantha holttumii has a crenulateundulate, incurved acuminate apex with a thick midvein that rises upwards. The labellum of $O$. sarawakensis on the other hand has an extended twisted midvein (2.6 cm long), prominently thick and curved upwards; this extended twisted labellum apex separates it from all other species in Orchidantha (Figure 2).

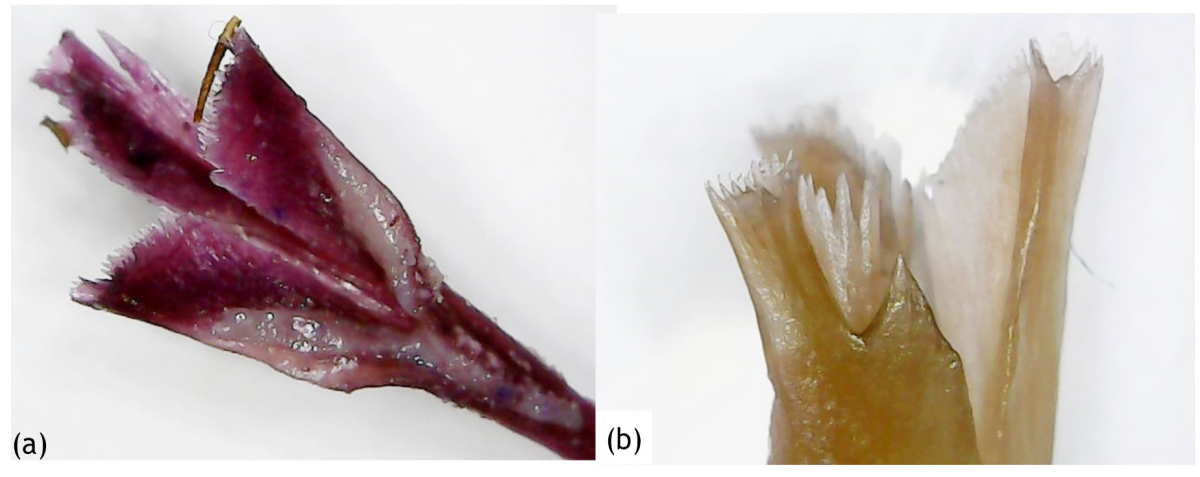

Figure 1 Stigma of Orchidantha sarawakensis, (a) whitish purple Y-shaped viscidium and (b) crenate and dentate stigma margin

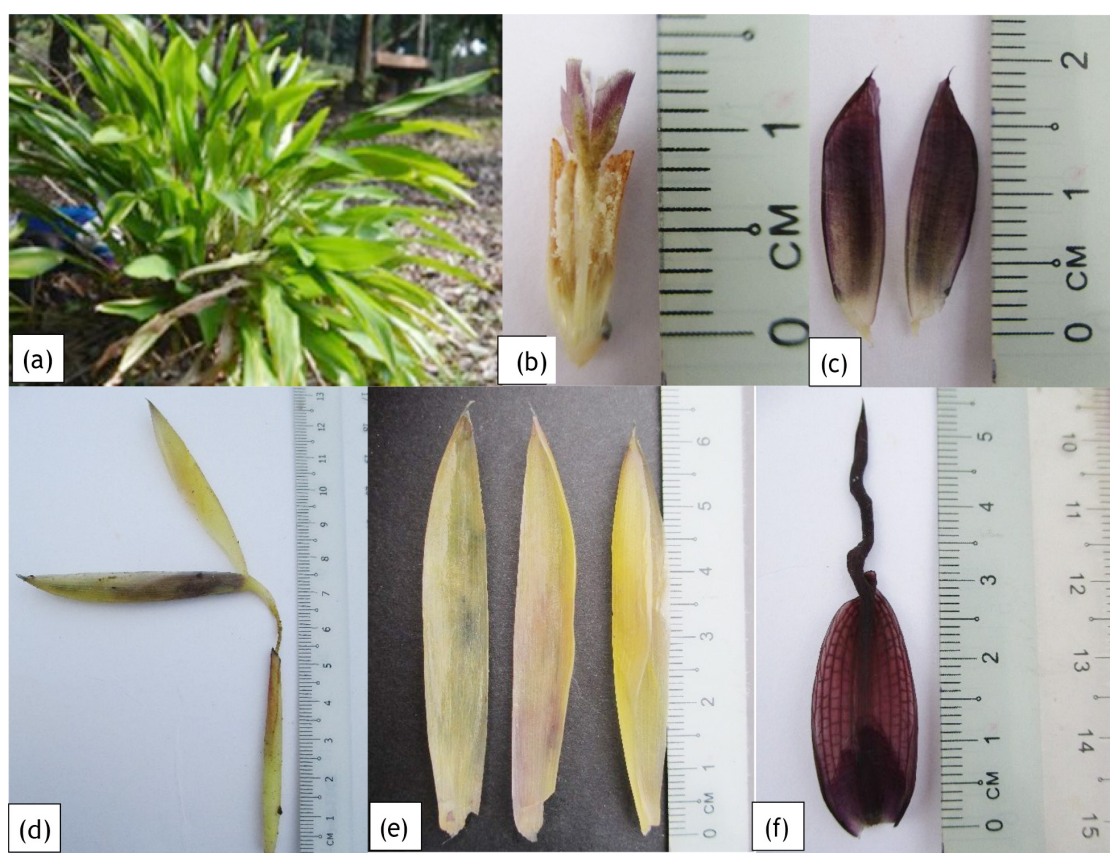

Figure 2 Orchidantha sarawakensis sp. nov., (a) plant habit, (b) stigma with stamen, (c) petal, (d) flower, (e) sepal and (f) labellum 
Further differences between the three species are in the stigma structure. Orchidantha has a specialised secretion tissue called viscidium that develops basally and ventrally on the stigma (Glinos \& Cocucci 2011) and is the most important part in the stigma to be observed. Each species has a distinct viscidium shape, and the species can be identified by observing the stigma alone (Pedersen \& Johansen 2004). Orchidantha megalantha has a V-shaped viscidium, O. holttumii a broadly V-shaped viscidium, and O. sarawakensis a Y-shaped viscidium.

By close observation of the stigma, differences in the margins between the three species can be
seen-O. megalantha has a minutely laciniate margin, O. holttumii a minutely fimbriate margin, and $O$. sarawakensis, a crenate and dentate margin. Also, the colours of the stigma of the three species are different-purple in Orchidantha megalantha, white-cream in $O$. holttumii and dark purple in $O$. sarawakensis. An illustration of the new species is given in Plate 1 . The differences between three species are summarised in Table 1.

Based on morphological vegetative and reproductive character within this study, a key of Orchidantha genus in Malaysia was produced as follows:

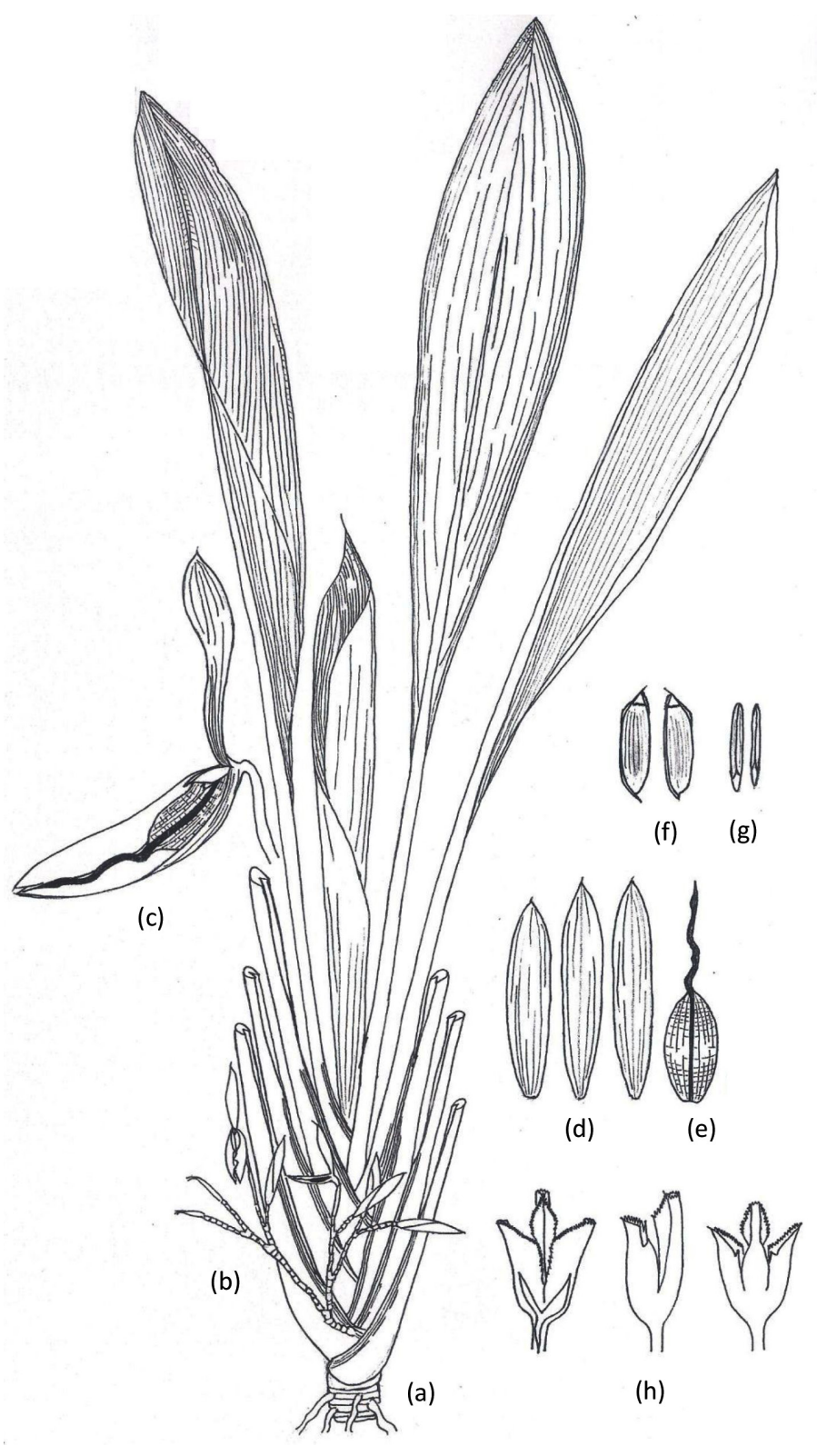

Plate 1 Botanical illustration of Orchidantha sarawakensis Syauqina \& Meekiong, (a) plant habit, (b) inflorescence, (c) flower, (d) sepals, (e) labellum, (f) petals, (g) stamen and (h) stigma; illustration by Syauqina MY 


\section{KEYTO THE MALAYSIAN SPECIES OF ORCHIDANTHA}

1a Petiole sheath with wide wing, continuous in the leaf blade base $\quad 2$

1b Petiole sheath with wing, distantly separate from leaf blade base

2a Petal white with purple tip, stigma white, viscidium V-shaped

O. sabahensis

10a Stigma size, ca. $12.1 \mathrm{~mm} \times 9.2 \mathrm{~mm}$, yellow green

11a Stigma with fimbriate crest margin

O. borneensis

11b Stigma with toothed margin.

12a Viscidium narrowly V-shaped with purple colour

O. maxillarioides

12b Viscidium broadly U-shaped with light yellow colour

O. lengguanii

13a Stigma with undulate margin, viscidium sharp V-shaped

O. ranchanensis

13b Stigma crenate and minutely fimbriate, viscidium broadly V-shaped

O. inouei

14a Petal lanceolate with maroon colour.

O. siamensis

14b Petal linear with cream/white colour

15a Stigma size ca. $2.5 \mathrm{~mm} \times 0.4 \mathrm{~mm}$, long toothed margin, translucent white $\quad$ O. fimbriata 
Table 1 Comparison of characters of Orchidantha sarawakensis sp. nov., O. megalantha and O. holttumii

\begin{tabular}{|c|c|c|c|c|}
\hline \multicolumn{2}{|l|}{ Character } & O. sarawakensis & O. holttumii & O. megalantha \\
\hline \multicolumn{2}{|c|}{ Leafy shoots (m) } & $1.5 \mathrm{~m}$ & $1-1.5 \mathrm{~m}$ & $1 \mathrm{~m}$ \\
\hline \multicolumn{2}{|c|}{ Petiole $(\mathrm{cm})$} & ca. $41-81$ & ca. $30-70$ & ca. 55 \\
\hline \multicolumn{2}{|l|}{ Leaf $(\mathrm{cm})$} & ca. $72.3 \times 12.4$ & ca. $30 \times 7$ & ca. $75.0 \times 15.5$ \\
\hline \multicolumn{2}{|c|}{ Sepals $(\mathrm{cm})$} & $\begin{array}{l}\text { ca. } 6.2 \times 1.2 \text {, oblanceolate, } \\
\text { yellowish green }\end{array}$ & $\begin{array}{l}\text { ca. } 12.6 \times 0.6 \text {, linear to } \\
\text { narrowly lanceolate, fresh } \\
\text { green }\end{array}$ & $\begin{array}{l}\text { ca. } 14.0 \times 3.9 \text {, narrowly elliptic, } \\
\text { yellowish green with slightly } \\
\text { rusty towards apex }\end{array}$ \\
\hline \multicolumn{2}{|l|}{ Petal $(\mathrm{cm})$} & $\begin{array}{l}\text { ca. } 1.8 \times 0.8 \text {, elliptic, dark } \\
\text { purple }\end{array}$ & $\begin{array}{l}\text { ca. } 3.0 \times 1.0 \text {, oblanceolate, } \\
\text { dark purple }\end{array}$ & $\begin{array}{l}\text { ca. } 4.1 \times 1.1 \text {, irregular elliptic, } \\
\text { dark purple }\end{array}$ \\
\hline \multirow[t]{3}{*}{ Labellum } & Size $(\mathrm{cm})$ & ca. $5.6 \times 1.2$ & ca. $12.2 \times 3.2$ & ca. $13.5 \times 12.5$ \\
\hline & $\begin{array}{l}\text { Shape and } \\
\text { colour }\end{array}$ & Widely elliptic, dark violet & $\begin{array}{l}\text { Broadly lanceolate, dark } \\
\text { purple }\end{array}$ & Elliptic, dark purple \\
\hline & Apex & $\begin{array}{l}\text { Aristate with extended } \\
\text { prominent spiral-like margin } \\
(2.6 \mathrm{~cm})\end{array}$ & Acuminate & Acuminate \\
\hline \multirow[t]{2}{*}{ Stigma } & Size $(\mathrm{cm})$ & ca. $7.4 \times 2.8$ & ca. $9.1 \times 7.2$ & ca. $17.0 \times 11.0$ \\
\hline & $\begin{array}{l}\text { Margin and } \\
\text { colour }\end{array}$ & $\begin{array}{l}\text { Crenate and dentate, dark } \\
\text { purple }\end{array}$ & Minutely fimbriate, purple & $\begin{array}{l}\text { Minutely laciniate, cream } \\
\text { white with purple tinge }\end{array}$ \\
\hline \multicolumn{2}{|c|}{ Viscidium shape } & $\mathrm{Y}$ & $\mathrm{V}$ & $\mathrm{V}$ \\
\hline
\end{tabular}

\section{ACKNOWLEDGEMENTS}

We thank Universiti Malaysia Sarawak for providing facilities and Forest Department Sarawak for granting us permission to conduct this research in Sarawak. Special thanks to Mohammad-Zahid ZA, Ivy GNM, Nur-Karimah $M$ and Salasiah $M$ for help in the field and laboratory.

\section{REFERENCES}

Brown NE. 1886. Orchidantha borneensis, a new genus of Scitamineae. The Gardeners' Chronicle 26: 519.

Carlquist S \& Schneider EL. 1988. Origins and nature of vessels in monocotyledons: 3 , Lowiaceae, with common on rhizome anatomy Blumea 43: 219-224.

Chadburn H. 2018. Orchidantha maxillarioides. The IUCN Red List of Threatened Species 2018: e.T22486390A224 86906. http:/ / dx.doi org/10.2305/IUCN.UK.20181.RLTS T22486390A22486906.en.

Glinos E \& Cocucci AA. 2011. Pollination biology of Canna indica (Cannaceae) with particular reference to the functional morphology of the style. Plant Systematics and Evolution 291: 49-58.
Jenjittikul T \& Larsen K. 2003. Orchidantha foetida (Lowiaceae) a new species from Thailand. Nordic Journal of Botany 22: 405-408.

KENG H. 1969. Notes on the flower of Orchidantha longiflora. Garden's Bulletin Singapore 24.

LARSEN K. 1996. Lowiaceae. Flora Malesiana (Series 1) 12: $763-774$.

LEONG-ŠKORNiČKovÁ J. 2014. Orchidantha lengguani (Lowiaceae). A new species from Peninsular Malaysia, and typification of $O$. maxillarioides. Gardens's Bulletin Singapore 66: 15-25.

Nagamasu H \& SAKaI S. 1999. Orchidantha inouei (Lowiaceae) a new species from Borneo. Nordic Journal of Botany 19: 149-152.

Poulsen AD \& Leong-ŠKorničková J. 2017. Two new Orchidantha species (Lowiaceae) from Borneo. Blumea 62: 157-162. https://doi.org/10.3767/ blumea.2017.62.02.08.

Syaudina MY, Meekiong K, Tawan CS \& Aimi-Syazana S. 2016. Orchidantha ranchanensis, a new species of Lowiaceae from Sarawak, Malaysia. Folia Malaysiana 17: $35-42$.

Pedersen LB. 2001. Four new species of Orchidantha (Lowiaceae) from Sabah. Nordic Journal of Botany 21: 121-128.

Pedersen LB \& Johansen B. 2004. Anatomy of the unusual stigma in Orchidantha (Lowiaceae). American Journal of Botany 91: 299-305. 